\title{
Pengaruh Ekstrak Ubi Ungu terhadap Glukosa Darah dan MDA Hepar Tikus Hiperglikemia
}

\author{
Annisa Pratiwi ${ }^{1}$, Yustini Alioes ${ }^{2}$, Dinda Aprilia ${ }^{3}$ \\ ${ }^{1}$ Fakultas Kedokteran Universitas Andalas, Padang \\ ${ }^{2}$ Bagian Biokimia Fakultas Kedokteran Universitas Andalas, Padang \\ ${ }^{3}$ Bagian IImu Penyakit Dalam Fakultas Kedokteran Universitas Andalas, Padang
}

\begin{abstract}
A B S T R A C T
Latar Belakang. Ubi jalar ungu mengandung senyawa antioksidan berupa antosianin, asam fenolat, vitamin A, C, dan E. Antioksidan dapat meredam kerusakan oksidatif pada sel beta pankreas sehingga mampu meningkatkan sekresi insulin serta mengurangi stres oksidatif pada DM.

Objektif. Penelitian ini bertujuan untuk mengetahui pengaruh pemberian ekstrak ubi jalar ungu terhadap kadar glukosa darah dan MDA hepar tikus hiperglikemia.

Metode. Penelitian ini merupakan true experimental dengan post-test only control group design. Sebanyak 24 ekor tikus dibagi menjadi empat kelompok, yaitu kontrol negatif (K-), kontrol positif $(\mathrm{K}+)$, perlakuan satu (P1), dan perlakuan dua (P2). Kelompok P1 dan P2 diinduksi aloksan dan diberikan ekstrak ubi jalar ungu dosis $150 \mathrm{mg} / \mathrm{kgBB}$ dan $200 \mathrm{mg} / \mathrm{kgBB}$ selama 21 hari.

Hasil. Terdapat perbedaan signifikan kadar glukosa darah antara kelompok P1 dan P2 dengan kelompok K+ dengan nilai $p=0,000$. Terdapat perbedaan signifikan kadar MDA hepar antara kelompok $\mathrm{P} 1$ dibandingkan $\mathrm{K}$ - dan $\mathrm{K}+$ dengan nilai $\mathrm{p}=$ 0,001 dan $\mathrm{p}=0,046$, kelompok $\mathrm{P} 2$ dibandingkan $\mathrm{K}$ - dan $\mathrm{K}+$ dengan nilai $p=0,037$ dan $p=0,001$.

Result. There were significant differences between $P 1$ and $P 2$ with the $K+$ group with $p$-value $=0,000$. There were significant difference between $P 1$ group with the $K$ - and $K+$ group with $p$ value $=0.001$ and $0,046, P 2$ compared to $K$ - and $K+$ group with $p$-value $=0.037$ and $p=0,001$.

Conclusion. Purple sweet potato extract can reduce the level of blood glucose level and MDA in liver tissues.

Keywords: Purple sweet potato, blood glucose, MDA level in liver tissues

\section{Apa yang sudah diketahui tentang topik ini?}

Ekstrak ubi jalar ungu diketahui memiliki efek terhadap penurunan kadar glukosa darah pada tikus hiperglikemia, selain itu juga meningkatkan status antioksidan darah.

\section{Apa yang ditambahkan pada studi ini?}

Studi ini membuktikan adanya efek ekstrak ubi jalar ungu terhadap penurunan kadar glukosa darah dan MDA hepar tikus yang merupakan indikator adanya stress oksidatif pada DM dengan dosis optimal yang diharapkan.
\end{abstract}

Kesimpulan. Ekstrak ubi jalar ungu berpengaruh dalam menurunkan kadar glukosa darah dan MDA hepar tikus hiperglikemia.

Kata kunci: ubi jalar ungu, glukosa darah, MDA hepar

Background. Purple sweet potato contains antioxidant compounds such as anthocyanin, phenolic acid, vitamin A, C, and $E$. Antioxidants can reduce oxidative damaged of mitochondria in the pancreatic beta-cell resulting an increase in insulin secretion and a decrease oxidative stress in DM patients.

Objective. This study aimed to determine the effect of giving purple sweet potato extract on blood glucose levels and liver MDA in hyperglycemic rats.

Method. This study was true experimental with a post-test only control group design. A total of 24 rats were divided into 4 groups, namely negative control $(K-)$, positive control $(K+)$, treatment one ( $P 1)$, and treatment two ( $P 2)$. $P 1$ and $P 2$ groups were induced by alloxan and given a purple sweet potato extract dose of $150 \mathrm{mg} / \mathrm{kg} \mathrm{bb}$ and $200 \mathrm{mg} / \mathrm{kg}$ bb for 21 days.

\section{CORRESPONDING AUTHOR}

Name: Annisa Pratiwi

Phone: +6282385865403

E-mail:annisapratiwi50@gmail.com

ARTICLE INFORMATION

Received: September $23^{\text {rd }}$, 2020

Revised: October $15^{\text {th }}, 2020$

Available online: October $31^{\text {st }}$, 2020 


\section{Pendahuluan}

Diabetes Melitus (DM) merupakan masalah kesehatan di seluruh dunia yang menjadi salah satu penyebab utama kesakitan dan kematian terutama di negara berkembang. Diabetes melitus adalah suatu kelompok penyakit metabolik yang ditandai dengan kondisi hiperglikemia sebagai akibat dari kelainan pada sekresi insulin, kerja insulin, ataupun keduanya. Kondisi hiperglikemia tersebut apabila berlangsung dalam jangka waktu yang lama akan menyebabkan kerusakan, disfungsi, dan kegagalan dari organ-organ tubuh seperti mata, ginjal, saraf, jantung dan pembuluh darah. Komplikasi yang ditimbulkan akibat diabetes menimbulkan beban finansial dan penurunan kualitas hidup penderita. ${ }^{1}$

Jumlah penderita DM di Indonesia terus mengalami peningkatan. Data International Diabetes Federation (IDF) pada tahun 2017 menunjukkan bahwa Indonesia menempati urutan ke- 6 di dunia dengan jumlah penderita DM sebanyak 10,3 juta orang. Berdasarkan estimasi IDF, akan terjadi peningkatan sebesar $48 \%$, yaitu sekitar 425 juta orang dewasa di dunia menderita diabetes. Diperkirakan jumlah ini akan terus meningkat jika tidak dilakukan tindakan pencegahan dan diprediksi pada tahun 2045 meningkat menjadi 629 juta penderita. Angka mortalitas dunia pada tahun 2017 adalah 3,2-5 juta kematian akibat DM pada rentang usia 20-79 tahun dan dapat diperkirakan bahwa setiap 8 detik ada 1 orang yang meninggal karena diabetes melitus. $^{2}$ Sementara itu, prevalensi DM yang terdiagnosis dokter di Indonesia menurut konsensus PERKENI 2015 pada penduduk usia $\geq$ 15 tahun berdasarkan Riskesdas 2018 sebesar 10,9\%. Prevalensi DM berdasarkan data tersebut mengalami peningkatan dibandingkan tahun 2013. Berdasarkan data Riskesdas 2018, prevalensi DM di Sumatera Barat sebesar 1,75\%. ${ }^{3}$

Kondisi hiperglikemia pada penderita diabetes melitus menyebabkan kerusakan jaringan melalui berbagai mekanisme, meliputi peningkatan proses autooksidasi glukosa, glikasi protein, dan aktivasi jalur metabolisme poliol yang selanjutnya akan mempercepat pembentukan senyawa oksigen reaktif. ${ }^{4}$ Hati merupakan salah satu organ utama yang rentan terhadap efek hiperglikemia yang menyebabkan stres oksidatif sehingga bisa mengarah ke kerusakan hati. Hal ini diikuti oleh gangguan pada metabolisme protein, karbohidrat, dan lemak yang meningkatkan stres oksidatif dan memicu respon inflamasi. Pada penderita DM terjadi akumulasi berlebihan dari sel lemak di hati yang menyebabkan perlemakan hati non alkoholik (NAFL). Prevalensi penderita diabetes tipe 2 yang menderita NAFLD di USA sebesar 33-50\%, sementara itu di Indonesia penelitian yang dilakukan pada pasien di Rumah Sakit Cipto Mangunkusumo prevalensinya 45,2\%. ${ }^{5}$

Salah satu target utama dari senyawa oksigen reaktif yang terbentuk akibat hiperglikemia adalah lipid. Radikal peroksil terbentuk ketika Poly Unsaturated Fatty Acid (PUFA) berinteraksi dengan oksigen dan sering digunakan sebagai penanda stres oksidatif. Salah satu penanda primer dari radikal bebas yang berasal dari peroksidasi lemak adalah malondialdehid (MDA). Peningkatan kadar MDA di plasma, hepar, dan jaringan telah dilaporkan pada pasien diabetes. ${ }^{6}$

Seiring dengan meningkatnya kasus DM di Indonesia, maka diperlukan tatalaksana yang tepat untuk menurunkan kadar glukosa darah dan mencegah terjadinya komplikasi akibat DM. Tatalaksana yang diperlukan meliputi perubahan gaya hidup berupa diet dan aktifitas fisik serta penggunaan obat-obatan. Obat-obatan yang sering dikonsumsi adalah golongan sulfonilurea, biguanida, dan akarbose, namun obat tersebut memiliki efek samping yang dapat membahayakan pasien. Efek samping yang ditimbulkan dari obat yang beredar menimbulkan gagasan dari para ahli untuk mengembangkan pengobatan herbal sebagai obat DM yang lebih aman. ${ }^{7}$

Penelitian yang dikembangkan oleh para ahli terbukti memberikan hasil yang baik pada cukup banyak pasien yang diberikan pengobatan herbal. Hal ini disebabkan oleh efek samping yang minimal dari pengobatan herbal tersebut sehingga sering dipertimbangkan sebagai terapi DM. Berdasarkan rekomendasi WHO, agen hipoglikemik dari pengobatan herbal penting dalam pengelolaan diabetes. ${ }^{7}$

Salah satu tanaman yang dapat dijadikan terapi alternatif untuk DM adalah ubi jalar ungu. Ubi jalar ungu memiliki keunggulan berupa indeks glikemik yang rendah serta kandungan antioksidan yang tinggi dibandingkan dengan ubi jalar lainnya. Antioksidan dalam ubi ungu berasal dari vitamin $A$, vitamin $C$, serta pigmen antosianin yang menyebabkan umbinya berwarna ungu. ${ }^{8}$ 
Antioksidan dapat memperbaiki mitokondria sel beta pankreas yang rusak oleh radikal bebas sehingga mampu meningkatkan sekresi insulin pankreas serta mengurangi stres oksidatif pada DM. ${ }^{9}$

Hasil penelitian menunjukkan bahwa ekstrak etanol ubi jalar ungu (Ipomoea batatas $c V$ Ayamurasaki) dengan dosis $200 \mathrm{mg} / \mathrm{kg} \mathrm{BB}$ dan $400 \mathrm{mg} / \mathrm{kg}$ BB menurunkan kadar glukosa darah mencit dengan rata-rata sebesar $50,48 \%$ dan 50,23\%.10 Penelitian lain membuktikan bahwa pemberian ekstrak antosianin ubi jalar ungu dosis $40 \mathrm{mg} / 200 \mathrm{~g}$ BB selama 4 minggu dapat menurunkan glukosa darah sebesar $33,23 \%$ dan mampu memperbaiki histopatologi sel $\beta$ pankreas pada tikus yang diinduksi aloksan. ${ }^{11}$

Berdasarkan data-data tersebut, maka perlu dilakukan penelitian lebih lanjut mengenai pengaruh pemberian ekstrak ubi jalar ungu terhadap glukosa darah dan malondialdehid (MDA) hepar tikus hiperglikemia yang diinduksi aloksan.

\section{Metode}

Penelitian ini merupakan penelitian eksperimental dengan rancangan Posttest Only Control Group. Tikus (Rattus norvegicus) galur wistar yang dibagi dalam 4 kelompok yaitu kelompok kontrol negatif $(\mathrm{K}+)=$ kelompok yang tidak diinduksi aloksan, kelompok kontrol positif $(\mathrm{K}+)=$ kelompok yang hanya diinduksi aloksan saja, kelompok perlakuan satu (P1) = kelompok yang diinduksi aloksan dan diberikan ekstrak ubi jalar ungu dosis $150 \mathrm{mg} / \mathrm{kgBB}$, kelompok perlakuan dua (P2) = kelompok yang diinduksi aloksan dan diberikan ekstrak ubi jalar ungu dosis $200 \mathrm{mg} / \mathrm{kgBB}$. Tikus dinyatakan hiperglikemia apabila kadar kadar glukosa darah puasa $>135$ $\mathrm{mg} / \mathrm{dl} .{ }^{12}$

Pembuatan ekstrak ubi jalar ungu dengan cara maserasi selama 3 hari dengan menggunakan pelarut etanol 70\%. Ekstrak ubi jalar ungu diberikan menggunakan sonde setiap hari selama 21 hari. Pengambilan sampel dilakukan pada hari ke-21. Sampel untuk pengukuran kadar glukosa darah yaitu serum yang diambil dari sinus orbitalis tikus. Sampel yang digunakan untuk pengukuran kadar MDA diambil melalui pembedahan pada tikus setelah tikus dibunuh dengan cara dislokasi leher, lalu diambil organ hati dan dibuat homogenatnya. Kadar glukosa darah diperiksa dengan metode enzymatic colorimetric test GOD-PAP dan kadar MDA diperiksa dengan metode TBARS (Thiobarbituric Acid Reactive Substance). Penelitian ini telah lolos uji etik dengan nomor surat: 623/KEP/FK/2019.

Pengolahan data dengan menggunakan analisis univariat yaitu uji normalitas Shapiro-Wilk. Langkah selanjutnya dengan analisis bivariat dengan menggunakan uji parametrik One Way ANOVA apabila data terdistribusi normal dan homogen, dilanjutkan Post Hoc Test dengan LSD (Least Significant Difference).

Hasil

Penelitian mengenai pengaruh pemberian ekstrak ubi jalar ungu terhadap glukosa darah dan MDA hepar tikus hiperglikemia yang diinduksi aloksan telah dilakukan di Laboratorium Biokimia Fakultas Kedokteran Universitas Andalas, Laboratorium Fakultas Farmasi Universitas Andalas, dan Laboratorium Biomedik Fakultas Kedokteran Universitas Andalas. Penelitian dilakukan selama 35 hari. Penelitian ini dilakukan pada 24 ekor tikus yang berusia 8-12 minggu dengan berat badan sekitar 150-200 gram yang dibagi menjadi 4 kelompok, yaitu kontrol negatif, kontrol positif, dan 2 kelompok perlakuan yang diberikan ekstrak ubi jalar ungu dosis 150 $\mathrm{mg} / \mathrm{kgBB}$ dan $200 \mathrm{mg} / \mathrm{kgBB}$ selama 21 hari.

Hasil pengukuran kadar glukosa darah tikus setelah diberikan perlakuan selama 21 hari dapat dilihat pada tabel 1 .

Tabel 1. Hasil Pengukuran Kadar Glukosa Darah Setelah Perlakuan

\begin{tabular}{ccccc}
\hline \multirow{2}{*}{ No } & \multicolumn{4}{c}{ Glukosa Darah (mg/dL) } \\
\cline { 2 - 5 } & K (-) & K (+) & P1 & P2 \\
\hline 1 & 75,1 & 408,5 & 139,3 & 134,9 \\
2 & 90,8 & 326,5 & 154,8 & 135,9 \\
3 & 105,2 & 338,4 & 165,5 & 96,7 \\
4 & 114,1 & 262,1 & 130,9 & 106,4 \\
5 & 138 & 394,1 & 161,5 & 173,2 \\
\hline Rerata & $104,64 \pm$ & $345,92 \pm$ & $150,4 \pm$ & $129,42 \pm$ \\
\pm SD & 23,81 & 58,52 & 14,78 & 29,96 \\
\hline
\end{tabular}

Tabel 1 menunjukkan kadar glukosa darah tikus setelah diberikan perlakuan selama 21 hari. Rerata kadar glukosa darah tertinggi terdapat pada kontrol positif $(\mathrm{K}+)$ yaitu $345,92 \pm 58,52$ $\mathrm{mg} / \mathrm{dl}$. Rerata kadar glukosa darah terendah 
terdapat pada kontrol negatif (K-) yaitu 104,64 \pm 23,81 mg/dl. Tikus yang diinduksi aloksan dan diberikan ekstrak ubi jalar ungu dosis 150 $\mathrm{mg} / \mathrm{kgBB}$ (P1) dan dosis $200 \mathrm{mg} / \mathrm{kgBB}$ (P2) memiliki kadar glukosa darah yang lebih rendah dari kontrol positif $(\mathrm{K}+)$ yaitu $150,4 \mathrm{mg} / \mathrm{dl}$ dan $129,42 \mathrm{mg} / \mathrm{dl}$.

Peningkatan kadar glukosa darah tikus setelah diinduksi aloksan dapat menyebabkan peningkatan peroksidasi lipid yang ditunjukkan oleh peningkatan kadar MDA hepar. Pengambilan hepar tikus dilakukan pada hari terakhir penelitian yaitu hari ke-21 untuk diukur konsentrasi MDA. Hasil pengukuran kadar MDA hepar dapat dilihat pada tabel 2.

Tabel 2. Kadar MDA Hepar Tikus Setelah Perlakuan

\begin{tabular}{ccccc}
\hline \multirow{2}{*}{ No } & \multicolumn{4}{c}{ Kadar MDA hepar (nmol/mg) } \\
\cline { 2 - 5 } & K (-) & K (+) & P1 & P2 \\
\hline 1 & 6,68 & 9,9 & 7,27 & 8,72 \\
2 & 7,99 & 11,27 & 10,72 & 8,12 \\
3 & 6,21 & 11,55 & 10,4 & 8,66 \\
4 & 6,24 & 10,63 & 10,53 & 8,66 \\
5 & 7,47 & 11,61 & 8,82 & 10,06 \\
\hline Rerata & $6,92 \pm$ & $10,99 \pm$ & $9,55 \pm$ & $8,84 \pm$ \\
\pm SD & 0,79 & 0,72 & 1,48 & 0,72 \\
\hline
\end{tabular}

Tabel 2 memperlihatkan rerata kadar MDA hepar pada setiap kelompok penelitian setelah diberikan perlakuan selama 21 hari. Rerata kadar MDA hepar tertinggi terdapat pada kontrol positif $(\mathrm{K}+)$ yaitu 10,78 nmol/mg. Rerata kadar MDA hepar terendah terdapat pada kontrol negatif (K-) yaitu 7,07 nmol/mg. Tikus yang diinduksi aloksan dan diberikan ekstrak ubi jalar ungu dosis 150 $\mathrm{mg} / \mathrm{kgBB}$ (P1) dan dosis $200 \mathrm{mg} / \mathrm{kgBB}$ (P2) memiliki kadar MDA hepar yang lebih rendah dari kontrol positif yaitu $9,48 \mathrm{nmol} / \mathrm{mg}$ dan 8,44 $\mathrm{nmol} / \mathrm{mg}$.

Hasil uji one-way ANOVA terhadap kadar glukosa darah setelah perlakuan selama 21 hari menunjukan nilai $\mathrm{p}<0,05$, ini menunjukkan terdapat perbedaan yang bermakna $(\mathrm{p}=0.000)$ kadar glukosa darah antar kelompok perlakuan setelah perlakuan selama 21 hari.

Tabel 3. Hasil Analisis LSD Kadar Glukosa Darah Setelah Perlakuan Selama 21 Hari

\begin{tabular}{ccccc}
\hline Kelompok & K- & K+ & P1 & P2 \\
\hline K- & & $0,000^{*}$ & 0,075 & 0,163 \\
K+ & $0,000^{*}$ & & $0,000^{*}$ & $0,000^{*}$ \\
P1 & 0,075 & $0,000^{*}$ & & 0,672 \\
P2 & 0,163 & $0,000^{*}$ & 0,672 & \\
\hline
\end{tabular}

Keterangan: ${ }^{*}=$ terdapat perbedaan yang bermakna $(\mathrm{p}<0,05)$
Tabel 3 menunjukkan adanya perbedaan yang signifikan pada kelompok kontrol positif dengan kontrol negatif, perlakuan satu, dan perlakuan dua dengan nilai $p=0,000$. Tidak terdapat perbedaan yang signifikan antara perlakuan satu dan perlakuan dua dengan nilai $\mathrm{p}=0,672$, kontrol negatif dengan perlakuan satu dan perlakuan dua dengan nilai $p=0,075$ dan 0,163 .

Hasil uji one way ANOVA terhadap kadar MDA hepar menunjukan nilai $\mathrm{p}<0,05$, ini menunjukkan terdapat perbedaan yang bermakna $(p=0.000)$ kadar MDA hepar antar kelompok perlakuan setelah pemberian ekstrak ubi jalar ungu selama 21 hari. Analisis data selanjutnya bertujuan untuk mengetahui perbedaan signifikan pada masingmasing kelompok dengan uji Post-Hoc yaitu Least Significant Differences (LSD).

Tabel 4. Hasil Analisis LSD kadar MDA hepar

\begin{tabular}{|c|c|c|c|c|}
\hline Kelompok & K- & $\mathrm{K}+$ & P1 & P2 \\
\hline $\mathrm{K}-$ & & $0,000^{*}$ & $0,001^{*}$ & $0.007^{*}$ \\
\hline $\mathrm{K}+$ & $0,000 *$ & & $0,034 *$ & $0,003^{*}$ \\
\hline P1 & $0,001 *$ & $0,034^{*}$ & & 0,274 \\
\hline P2 & $0,007^{*}$ & $0,003 *$ & 0,274 & \\
\hline
\end{tabular}

Tabel 4 menunjukkan adanya perbedaan kadar MDA hepar yang signifikan antara kelompok perlakuan satu dengan kontrol negatif dan kontrol positif dengan nilai $\mathrm{p}=0,001$ dan $\mathrm{p}=0,034$, kelompok perlakuan dua dengan kontrol negatif dan kontrol positif dengan nilai $p=0,007$ dan $\mathrm{p}=0,003$. Tidak terdapat perbedaan yang signifikan antara perlakuan satu dan perlakuan dua dengan nilai $p=0,274$.

\section{Pembahasan}

\section{Pengaruh Induksi Aloksan terhadap Kadar Glukosa Darah}

Penelitian ini dilakukan pada 24 ekor tikus dan dibagi menjadi 4 kelompok, yaitu kelompok kontrol negatif, kelompok kontrol positif, dan 2 kelompok perlakuan yang diberikan ekstrak ubi jalar ungu dengan dosis $150 \mathrm{mg} / \mathrm{kgBB}$ dan 200 $\mathrm{mg} / \mathrm{kgBB}$ selama 21 hari. Tikus diinduksi aloksan dengan dosis $125 \mathrm{mg} / \mathrm{kgBB}$ secara intraperitoneal untuk menimbulkan efek hiperglikemia. Glukosa darah tikus kemudian diukur pada hari kelima setelah induksi aloksan dengan menggunakan glukometer. Kadar glukosa darah puasa tikus hiperglikemia yang digunakan dalam penelitian ini adalah $>135 \mathrm{mg} /$ dl. Terdapat perbedaan dalam 
peningkatan kadar glukosa darah tikus setelah diinduksi aloksan, hal ini dapat dipengaruhi oleh respon individual dari hewan coba.

Aloksan menyebabkan kenaikan kadar glukosa darah puasa tikus diatas nilai normal yaitu 50-135 $\mathrm{mg} / \mathrm{dl} .{ }^{12}$ Senyawa aloksan dan produk reduksinya berupa asam dialurik membentuk siklus redoks dengan formasi berupa radikal superoksida. Radikal yang terbentuk kemudian akan mengalami dismutase menjadi hidrogen peroksida. Aktivitas radikal bebas yang mendapat rangsangan yang tinggi meningkatkan konsentrasi kalsium di sitosol yang menyebabkan destruksi yang cepat pada sel-sel $\beta$ pankreas. Aloksan juga meningkatkan permeabilitas sel $\beta$ pankreas yang ditunjukkan dengan pengeluaran ion kalsium dari mitokondria yang mengakibatkan gangguan homeostasis yang merupakan awal dari kematian sel. Kerusakan sel $\beta$ pankreas diikuti dengan penurunan sekresi insulin dan mengakibatkan peningkatan kadar glukosa darah. ${ }^{13}$

\section{Pengaruh Pemberian Ekstrak Ubi Jalar Ungu Terhadap Kadar Glukosa Darah}

Tikus yang telah menunjukkan kondisi hiperglikemia diberi perlakuan dengan dua dosis ekstrak ubi jalar ungu selama 21 hari. Hasil yang didapatkan setelah tikus diberikan perlakuan selama 21 hari yaitu rata-rata kadar glukosa darah tikus mengalami penurunan pada kelompok yang diberikan ekstrak ubi jalar ungu (Tabel 1).

Hasil pengukuran kadar glukosa darah pada masing-masing kelompok adalah sebagai berikut. Kelompok kontrol negatif merupakan tikus normal yang tidak diinduksi aloksan dan tidak diberikan ekstrak ubi jalar ungu. Kadar glukosa darah puasa kelompok kontrol negatif dianggap sebagai pembanding yang normal dengan rerata kadar glukosa darah puasa yaitu 104,64 mg/dl.

Rerata kadar glukosa darah puasa kelompok kontrol positif yang hanya diinduksi aloksan saja yaitu 345,92 mg/dl. Kadar glukosa darah tersebut lebih tinggi dan berbeda signifikan dengan kelompok lainnya dan menunjukkan bahwa tikus mengalami hiperglikemia atau diabetes eksperimental. Hal ini disebabkan karena induksi aloksan yang menimbulkan efek hiperglikemia pada tikus. Aloksan bersifat toksik selektif terhadap sel beta pankreas yang memproduksi insulin. Aloksan dan produk reduksinya berupa asam dialurik meningkatkan aktivitas radikal bebas yang diikuti dengan peningkatan kalsium di sitosol sehingga terjadi destruksi cepat dari sel beta pankreas. Kerusakan sel $\beta$ pankreas diikuti dengan penurunan sekresi insulin dan mengakibatkan peningkatan kadar glukosa darah. ${ }^{13}$

Rerata kadar glukosa darah puasa kelompok perlakuan satu dan dua mengalami penurunan dari kadar glukosa darah awal setelah 21 hari dan lebih rendah jika dibandingkan dengan kelompok kontrol positif. Kelompok perlakuan dua yang diberikan ekstrak ubi jalar ungu dosis 150 $\mathrm{mg} / \mathrm{kgBB}$ menunjukkan kadar glukosa darah tikus yang lebih rendah dibandingkan dengan perlakuan satu yang diberikan ekstrak ubi jalar ungu dosis $150 \mathrm{mg} / \mathrm{kgBB}$. Uji statistik One Way ANOVA menunjukkan adanya pengaruh pemberian ekstrak ubi jalar ungu terhadap kadar glukosa darah dengan nilai $\mathrm{p}<0,05$.

Uji Post Hoc dengan Least Significant Differences (LSD) menunjukkan adanya perbedaan signifikan antara kelompok kontrol positif dengan kontrol negatif, perlakuan satu, dan perlakuan dua. Tidak terdapat perbedaan yang signifikan antara perlakuan satu dan perlakuan dua, kontrol negatif dengan perlakuan satu dan perlakuan dua. Hasil tersebut menunjukkan kelompok perlakuan dengan ekstrak ubi jalar ungu dosis $150 \mathrm{mg} / \mathrm{kgBB}$ dan $200 \mathrm{mg} / \mathrm{kgBB}$ memiliki efektivitas yang hampir sama dalam menurunkan kadar glukosa darah tikus dan mendekati kadar glukosa darah kelompok kontrol negatif.

Ekstrak ubi jalar ungu terbukti dapat menghambat peningkatan kadar glukosa darah tikus hiperglikemia yang diinduksi aloksan. Hasil penelitian ini sesuai dengan penelitian yang dilakukan oleh Ni Wayan Wahyuni Ningrum yang membuktikan bahwa ekstrak etanol ubi jalar ungu (Ipomoea batatas $c v$ Ayamurasaki) dengan dosis $200 \mathrm{mg} / \mathrm{kg}$ BB dan $400 \mathrm{mg} / \mathrm{kg}$ BB dapat menurunkan kadar glukosa darah mencit diabetes yang diinduksi aloksan ${ }^{10}$ dan penelitian Ervika Rahayu yang membuktikan adanya penurunan kadar glukosa darah setelah pemberian ekstrak antosianin ubi jalar ungu dosis $40 \mathrm{mg} / 200 \mathrm{gBB}$ selama 4 minggu pada tikus yang diinduksi aloksan. ${ }^{11}$ 
Penurunan glukosa darah tikus setelah pemberian ekstrak ubi jalar ungu dapat disebabkan oleh kandungan zat gizi yang terdapat di dalamnya. Penelitian yang dilakukan oleh Teow dkk menunjukkan bahwa ubi jalar ungu mengandung senyawa antioksidan berupa antosianin, asam fenolat, tokoferol (vitamin E), lutein, zeaxanthin, dan beta karoten. ${ }^{14}$ Sebagai senyawa bioaktif, adanya susunan ikatan rangkap terkonjugasi pada struktur antosianin membuat antosianin mampu bertindak sebagai senyawa penghancur dan penangkal radikal bebas alami atau yang lebih dikenal sebagai senyawa antioksidan alami pada manusia. Proses penghambatan ini terjadi melalui mekanisme pemutusan rantai propagasi dari radikal bebas, dimana semua gugus hidroksil $(\mathrm{OH})$ pada cincin $\mathrm{B}$ dapat menyumbangkan atau berperan sebagai donor elektron atau hidrogen sehingga terjadi pembersihan atau pencegatan terhadap radikal bebas. ${ }^{15}$ Vitamin $\mathrm{E}$ dalam bentuk $\alpha$-tokoferol mampu menurunkan aktivitas protein kinase $\mathrm{C}$, yaitu enzim yang terkait langsung dengan peningkatan senyawa oksigen reaktif. Vitamin C dapat berperan sebagai inhibitor enzim aldose reduktase, sehingga penggunaan ekuivalen pereduksi berkurang dan dapat mencegah penumpukan sorbitol pada jaringan. ${ }^{16}$

Senyawa antioksidan yang terkandung dalam ekstrak ubi jalar ungu dapat menurunkan aktivitas radikal bebas dan meredam kerusakan oksidatif pada sel beta pankreas pada kondisi hiperglikemia melalui berbagai mekanisme. Hal ini menimbulkan perbaikan pada mitokondria sel beta pankreas, sehingga terjadi peningkatan sekresi insulin pankreas dan penurunan kadar glukosa darah. ${ }^{9}$

Dari uraian diatas, dapat disimpulkan bahwa pemberian dosis ekstrak ubi jalar ungu dengan dosis $150 \mathrm{mg} / \mathrm{kgBB}$ dan $200 \mathrm{mg} / \mathrm{kgBB}$ berpengaruh dalam menurunkan kadar glukosa darah tikus hiperglikemia yang diinduksi aloksan.

\section{Pengaruh Pemberian Ekstrak Ubi Jalar Ungu Terhadap Kadar MDA Hepar}

Tabel 2 menunjukkan kadar MDA hepar tikus setelah diberi perlakuan selama 21 hari. Rerata kadar MDA hepar pada kelompok kontrol positif yang hanya diinduksi aloksan saja adalah 10,78 \pm 0,83 $\mathrm{nmol} / \mathrm{mg}$ dan merupakan kelompok dengan kadar MDA hepar tertinggi diantara kelompok lainnya. Hal ini disebabkan oleh induksi aloksan pada kelompok kontrol positif yang mengakibatkan rusaknya sel beta pankreas tikus dan menyebabkan kenaikan glukosa darah tikus. Hiperglikemia meningkatkan produksi radikal bebas melalui tiga mekanisme, yaitu peningkatan aktivasi jalur poliol, glukoautooksidasi, dan glikasi protein. ${ }^{4}$ Radikal bebas bereaksi dengan PUFA (Poly Unsaturated Fatty Acid) sehingga terbentuk hidrogen peroksida. ${ }^{17}$ Ini mengakibatkan terputusnya rantai asam lemak menjadi berbagai senyawa yang toksik terhadap sel, antara lain Malondialdehid (MDA). ${ }^{4}$ Hepar merupakan tempat berbagai macam metabolisme, seperti lipolisis dan lipogenesis. Selain itu, lemak yang tinggi yang terdapat pada jaringan adiposa dan hasil konsumsi pakan terakumulasi di hepar. Lemak yang terdapat di hepar dapat bereaksi dengan radikal bebas sehingga terjadi peningkatan pada kadar MDA hepar. ${ }^{18}$

Rerata kadar MDA hepar pada kelompok kontrol negatif adalah 7,07 $\pm 0,8 \mathrm{nmol} / \mathrm{mg}$ dan merupakan kelompok dengan kadar MDA terendah diantara kelompok lainnya. Hal ini menunjukkan kadar MDA hepar dalam batas normal karena pada kelompok ini tikus tidak diinduksi aloksan dan tidak diberi perlakuan.

Kelompok perlakuan satu menunjukkan rerata kadar MDA hepar sebesar 9,48 $\pm 1,34 \mathrm{nmol} / \mathrm{mg}$. Hasil ini lebih rendah dibandingkan rata-rata kadar MDA hepar kelompok kontrol positif. Hasil uji LSD menunjukkan terdapat perbedaan yang signifikan antara perlakuan satu dengan kelompok kontrol negatif dan kontrol positif. Hal ini menunjukkan ekstrak ubi jalar ungu dosis 150 $\mathrm{mg} / \mathrm{kgBB}$ belum mampu memberikan efek yang optimal dalam menurunkan kadar MDA hepar meskipun dapat menurunkan kadar glukosa darah pada tikus. Efek penurunan yang tidak optimal ini dapat disebabkan oleh durasi perlakuan yang relatif singkat dan rendahnya dosis ekstrak ubi jalar ungu, sehingga hanya sedikit zat aktif yang berikatan dengan reseptor dan jumlah zat bebas dalam tubuh banyak. Ini menimbulkan efek yang tidak maksimal. ${ }^{19}$

Rerata kadar MDA hepar pada kelompok perlakuan dua dengan dosis $200 \mathrm{mg} / \mathrm{kgBB}$ yaitu $8,44 \pm 1,82 \mathrm{nmol} / \mathrm{mg}$, kadar ini lebih rendah dibandingkan kontrol positif dan perlakuan satu. Hasil uji LSD menunjukkan adanya perbedaan yang signifikan antara perlakuan dua dengan 
kontrol negatif dan kontrol positif. Kelompok perlakuan dua meskipun memiliki kadar MDA hepar yang lebih rendah dari perlakuan satu, namun tidak berbeda signifikan secara statistik dengan perlakuan satu. Hal ini dapat disebabkan oleh perbedaan dosis yang kecil antara perlakuan satu dan perlakuan dua sehingga kadar zat yang mencapai reseptor dan berikatan dengan reseptor hampir sama. ${ }^{20}$

Penurunan kadar MDA hepar yang terdapat pada kedua kelompok perlakuan disebabkan karena ekstrak ubi jalar ungu mengandung senyawa antioksidan berupa antosianin, asam fenolat, vitamin A, C, dan E. Hiperglikemia menyebabkan terjadinya pembentukan senyawa oksigen reaktif yang dapat meningkatkan modifikasi lipid yang salah satu hasil akhirnya yaitu berupa peningkatan kadar MDA. Modifikasi lipid pada berbagai jaringan mengakibatkan ketidakseimbangan antara antioksidan protektif dengan peningkatan produksi radikal bebas. ${ }^{21}$

Sejumlah penelitian membuktikan pemberian antioksidan, termasuk antosianin dapat melindungi sel $\beta$ pankreas dari stres oksidatif. Senyawa antioksidan yang terdapat dalam ekstrak ubi jalar ungu dapat menurunkan aktivitas radikal bebas sehingga radikal bebas yang bereaksi dengan PUFA pada membran sel berkurang dan terjadi penurunan produk akhir dari peroksidasi lipid yaitu MDA. Antosianin bekerja dengan cara menetralkan enzim yang dapat menghancurkan jaringan kolagen, sifat antioksidannya melindungi jaringan kolagen dari radikal bebas yang salah satunya dibuktikan oleh penurunan kadar MDA yang merupakan produk akhir peroksidasi lipid. ${ }^{22}$

Pada penelitian ini terlihat efek antioksidan dari ubi jalar ungu terhadap kadar MDA hepar pada tikus hiperglikemia yang terbukti dengan menurunnya kadar MDA hepar seiring bertambahnya dosis ekstrak ubi jalar ungu. Hal ini sesuai dengan penelitian Jawi dkk yang membuktikan bahwa pemberian ekstrak ubi jalar ungu dosis $0,55 \mathrm{ml} /$ hari dapat menurunkan kadar MDA darah, hati, jantung, dan usus pada mencit yang diberikan aktivitas fisik maksimal. Antosianin yang terdapat pada ekstrak ubi jalar ungu merupakan salah satu antioksidan yang mampu mencegah stres oksidatif in vivo. Pemberian ekstrak ubi jalar ungu yang mengandung antosianin dapat menurunkan kadar glukosa darah sehingga akan memperkecil terbentuknya AGEs dan pada akhirnya akan menurunkan MDA pada darah dan hati mencit setelah diberikan aktivitas fisik maksimal.23 Penelitian lain yang dilakukan oleh Fatihatul F dkk membuktikan bahwa pemberian ekstrak tape ubi ungu 3,5 $\mathrm{ml} /$ hari dapat menurunkan kadar MDA plasma tikus setelah aktivitas fisik maksimal. ${ }^{24}$

\section{Simpulan}

Berdasarkan hasil penelitian ini, dapat disimpulkan bahwa rerata kadar glukosa darah dan MDA hepar tikus yang hanya diberikan pakan standar adalah 109,5 mg/dl dan 7,07 nmol/mol, rerata kadar glukosa darah dan MDA hepar tikus yang hanya diinduksi aloksan saja adalah 329,8 $\mathrm{mg} / \mathrm{dl}$ dan 10,78 $\mathrm{nmol} / \mathrm{mg}$, rerata kadar glukosa darah dan MDA hepar tikus yang diberi perlakuan dengan ekstrak ubi jalar ungu dosis $150 \mathrm{mg} / \mathrm{kgBB}$ adalah $149,7 \mathrm{mg} / \mathrm{dl}$ dan $9,48 \mathrm{nmol} / \mathrm{mg}$, dan rerata kadar glukosa darah dan MDA hepar pada kelompok yang diberi perlakuan dengan ekstrak ubi jalar ungu dosis $200 \mathrm{mg} / \mathrm{kgBB}$ adalah 140,5 $\mathrm{mg} / \mathrm{dl}$ dan $8,44 \mathrm{nmol} / \mathrm{mg}$.

Terdapat perbedaan yang signifikan pemberian ekstrak ubi jalar ungu terhadap kadar glukosa darah tikus pada kelompok perlakuan dibandingkan kontrol positif. Terdapat perbedaan yang signifikan pemberian ekstrak ubi jalar ungu terhadap kadar MDA hepar tikus pada kelompok perlakuan dibandingkan kontrol positif dan kontrol negatif. Kelompok perlakuan dengan ekstrak ubi jalar ungu dosis $150 \mathrm{mg} / \mathrm{kgBB}$ dan $200 \mathrm{mg} / \mathrm{kgBB}$ memiliki efektivitas yang hampir sama dalam menurunkan kadar glukosa darah dan MDA hepar tikus.

\section{Ucapan Terima Kasih}

Penulis telah banyak mendapatkan bantuan dan dukungan dari berbagai pihak, oleh karena itu pada kesempatan ini penulis ingin menyampaikan rasa hormat dan terima kasih kepada seluruh pihak yang membantu sehingga penelitian ini dapat diselesaikan dengan baik.

\section{Daftar Pustaka}

1. American Diabetes Association. Diagnosis and Classification of Diabetes Mellitus. Diabetes Care. 2012; 35: 64-71. 
2. International Diabetes Federation (IDF). IDF Diabetes Atlas. Abu Dhabi: International Diabetes Federation; 2017.

3. Balitbang Kemenkes RI. Riset Kesehatan Dasar (RISKESDAS). Jakarta: Badan Penelitian dan Pengembangan Kesehatan RI; 2018.

4. Setiawan B, Suhartono. Stres Oksidatif dan Peran Antioksidan pada Diabetes Melitus. Majalah Kedokteran Indonesia. 2005; Vol 5 (2).

5. Prasetya IB, Hasan I, Wisnu W, Rumende CM. Prevalence and Profile of Fibrosis in Diabetic Patients with Non-Alcoholic Fatty Liver Disease and the Associated Factors. Indones J Intern Med. 2017; 49(2): 91-97.

6. Pandey KB, Tiwari BK. Markers of Oxidative Stress during Diabetes Mellitus. Journal of Biomarkers. 2013: 1-8.

7. Jayakumar RV. Herbal medicines for type-2 diabetes. Int J Diab Dev Ctries. 2010; 30 (3): 111.

8. Ginting E, Utomo JS, Yulifianti R, dan Jusuf M. Potensi Ubi Jalar Ungu sebagai Pangan Pungsional. Iptek Tanaman Pangan. 2011; 6(1): 116-138.

9. Widowati W. Potensi Antioksidan sebagai Antidiabetes. Jurnal Kedokteran Maranatha. 2008; 7(2): 193-202.

10. Ningrum NW. Uji Aktivitas Antidiabetes Ekstrak Etanol Ubi Jalar Ungu (Ipomoea batatas cv. Ayamurasaki) Terhadap Kadar Glukosa Darah Tikus yang Diinduksi Aloksan (skripsi). Jember: Universitas Jember; 2013.

11. Wicaksono LA, Yunianta, dan Widyaningsih TD. Anthocyanin Extraction from Purple Sweet Potato Cultivar Antin-3 (Ipomoea batatas L .) using Maceration, Microwave Assisted Extraction, Ultrasonic Assisted Extraction, and Their Application as Anti-Hyperglycemic Agents in Alloxan-Induced Wistar Rats. International Journal of PharmTech Research. 2016; 9 (3): 181-192.

12. Delaney, Cathy A. Johnson. Exotic Companion Medicine Handbook for Veterinarians. Zoological Education Network; 2008: 98.

13. Szkudelski. The Mechanism of Alloxan and Streptozotocin Action in B Cells of the Rat Pancreas. Physiol. Res. 2001; 50: 536-546.

14. Teow C.C., Truong V.D., Mc Feeters RF, Thompson RL, Pecota KV, Yencho GC. Antioxidant activities, phenolic and $\beta$-carotene contents of sweet potato genotypes with varying flesh colors. Food Chemistry. 2007; 103: 829-238.

15. Melania PI, Natalia P, Ludovicus C, Yulius DN. Review : Antosianin dan Pemanfaatannya. Cakra Kimia (Indonesian E-Journal of Applied Chemistry). 2018. 6 (2): 84-85.

16. Bambang S. Eko S. Stres Oksidatif dan Peran Antioksidan pada Diabetes Melitus. Maj Kedokt Indon. 2005. 55 (2): 89-90.
17. Robertson RP, Harmon J, Tran PO, Poitout V. $\beta$ cell Glukosa Toxicity, Lipotoxicity, and Chronic Oxidative Stress in Type 2 Diabetes. J Biol Chem. 2004; 279 (41): 42351-42354.

18. Ponziani FR, Pecere S, Gasbarrini A, Ojetti V. Physiology and pathophysiology of liver lipid metabolism [review]. Expert Rev Gastroenterol Hepatol. 2015. 9 (8): 1-13.

19. Katzung BG, ed. Farmakologi dasar dan klinik. 10th ed. Jakarta: Buku Kedokteran ECG; 2003:10-13.

20. Setiawati, A, Zunilda SB, Suyatna FD. Pengantar Farmakologi. Dalam: Farmakologi dan Terapi". Edisi 4. Jakarta: Fakultas Kedokteran Universitas Indonesia; 1995. hal. 14-16.

21. Bambang S. Eko S. Stres Oksidatif dan Peran Antioksidan pada Diabetes Melitus. Maj Kedokt Indon. 2005. 55 (2): 89-90.

22. Lucioli S. Anthocyanins: Mechanism of action and Therapeutic Efficacy. Research Signpost. 2012: 27-57.

23. Jawi IM, Suprapta DN, Dwi SU, Wiwiek I. Ubi Jalar Ungu Menurunkan Kadar MDA dalam Darah dan Hati Mencit Setelah Aktivitas Fisik Maksimal. Jurnal Veteriner. 2008; 9(2):65-72.

24. Fatihatul FM. Pengaruh Ekstrak Tape Ubi Ungu (Ipomoea batatas L.) Terhadap Kadar MDA Plasma Tikus Setelah Aktivitas Fisik Maksimal (skripsi). Semarang: Universitas Diponegoro; 2015. 